\title{
Pemilihan Web Browser Pada Mobile Menggunakan Metode Analytical Hierachy Process
}

\author{
Agustia Dwi Abdiati ${ }^{1}$, Santoso Setiawan², Hendra Supendar ${ }^{3}$ \\ ${ }^{1,2}$ Sekolah Tinggi Manajemen Informatika dan Komputer Nusa Mandiri \\ ${ }^{3}$ Universitas Bina Sarana Informatika \\ e-mail: ${ }^{1}$ agustiadwi2@gmail.com,${ }^{2}$ santoso.sts@ nusamandiri.ac.id, ${ }^{3}$ hendra.hds@ bsi.ac.id

\begin{tabular}{ccc}
\hline Diterima & Direvisi & Disetujui \\
$05-03-2021$ & $01-04-2021$ & $05-04-2021$ \\
\hline
\end{tabular}

\begin{abstract}
Abstrak - Ketika baru memiliki ponsel atau tablet android, pertama kali yang sering dipikirkan oleh pemiliknya adalah aplikasi wajib android yang harus di instal termasuk web browser. Karena kenyamanan dalam berinternet didukung oleh web browser yang digunakan. Web browser adalah perangkat lunak (software) yang digunakan untuk berselancar dalam dunia internet. Berkat kemajuan teknologi, saat ini web browser dapat digunakan pada mobile. Hal tersebut menjadikan para pengembang web bersaing untuk berinovasi menciptakan web browser yang dapat digunakan pada mobile. Untuk saat ini web browser yang populer adalah Chrome, Opera Mini, dan UC Browser. Dengan beragamnya pilihan yang ada, menjadikan para pengguna web browser bingung. Web browser apa yang terbaik untuk digunakan pada mobile dan sesuai dengan keinginan. Hal ini menjadi latar belakang penelitian, bagaimana menerapkan metode Analytical Hierarchy Process (AHP) untuk memilih web browser pada mobile. Penelitian ini bertujuan membuat sistem pendukung keputusan bagi pengguna internet, dalam menentukan pilihan mobile web browser yang tepat sesuai kriteria.
\end{abstract}

Kata Kunci : Web Browser, Analytical Hierarchy Process (AHP), Sistem Pendukung Keputusan

Abstract - When you just have an Android phone or tablet, the first thing the owner often thinks about is the mandatory Android application that must be installed, including a web browser. Because the convenience of the internet is supported by the web browser used. A web browser is software that is used to surf the internet. Thanks to technological advances, currently web browsers can be used on mobile. This makes web developers compete to innovate to create web browsers that can be used on mobile. For now, the popular web browsers are Chrome, Opera Mini, and UC Browser. With the variety of options available, it makes web browser users confused. What is the best web browser to use on mobile and according to your wishes. This is the background of the research, how to apply the Analytical Hierarchy Process (AHP) method to select web browsers on mobile. This study aims to create a decision support system for internet users, in determining the choice of the right mobile web browser according to the criteria.

Keywords: Web Browser, Analytical Hierarchy Process (AHP), Decision Support System

\section{PENDAHULUAN}

Indonesia merupakan negara dengan pengguna internet yang cukup besar. Berdasarkan data di Kementrian Komunikasi dan Informatika Republik Indonesia (KOMINFO), negara Indonesia menduduki peringkat ke 6 dalam penggunaan internet (Andiarna, Widayanti, Hidayati, Agustina, \& Kunci, 2020). Hal tersebut dapat disebabkan oleh kemajuan teknologi, karena saat ini internet dapat di akses di mobile kapan pun dan dimana pun (Minge, Thüring, Wagner, \& Kuhr, 2017).

Hal diatas menjadikan para pengembang web bersaing untuk berinovasi menciptakan web browser yang dapat digunakan pada mobile. Web browser adalah perangkat lunak yang digunakan untuk mengoperasikan internet (Rahmadoni, 2018). Web browser yang dapat digunakan pada mobile contohnya seperti Opera Mini, UC Browser, Chrome, Firefox, dan masih banyak lainnya.

Dengan banyaknya pilihan dan kelebihan yang dimiliki masing-masing mobile web browser, menjadikan para pengguna internet bingung untuk memilih web browser mana yang terbaik untuk digunakan (Fridayanthie et al., 2016). Sebelum menentukan web browser apa yang ingin digunakan, sebaiknya kenali terlebih dahulu kelebihan dan kekurangan web browser yang akan digunakan (Prasetiadi, 2011), agar tidak terjadi kesalahan dalam memilih web browser (Andri Sulistyo, 2016).

Semakin berkembangnya browser baik segi performansi maupun jumlah yang kerap membuat pengguna bingung untuk memilih dan tidak memanfaatkan fitur yang ditawarkan browser secara penuh . Dengan melakukan analisis perbandingan dan pembuatan panduan pemilihan browser, 
pengguna diharapkan dapat memilih browser secara lebih objektif dan sesuai dengan kebutuhan (Gandys Marisha Utami, 2018).

Dalam memilih mobile web browser dapat digunakan metode untuk mendukung pengambilan keputusan (Yosua, Agus, \& Astuti, 2017), metode yang dapat digunakan yaitu metode Analytical Hierarchy Process (AHP). AHP adalah prosedur yang berbasis matematis untuk mengevaluasi kriteria-kriteria yang disediakan (Fadli, Taufan, \& Zaen, 2018). AHP juga memperhitungkan validitas data dengan adanya batas toleransi inkonsistensi berbagai kriteria yang dipilih (Mujiastuti, Meilina, \& Afridhon Iwan Pramudiaji, 2017).

\section{METODE PENELITIAN}

Untuk mencapai tujuan penelitian maka diperlukan metode analisis data. Metode analisis data yang digunakan dalam penelitian ini adalah metode Analytical Hierarchy Process (AHP). Dengan jumlah kriteria sebanyak 5 kriteria dan 3 alternatif yang dipilih berdasarkan pertimbangan.

Berikut tahapan yang dilakukan dalam menerapkan metode AHP dalam pengambilan keputusan:

1. Mendefinisikan masalah dan menentukan solusi yang diinginkan, lalu menyusun hierarki dari permasalahan pada penelitian ini. Penyusunan hierarki adalah dengan menetapkan tujuan yang merupakan sasaran sistem secara keseluruhan pada level teratas, dimana tujuan pada penelitian ini yaitu untuk mengetahui web browser apa yang paling banyak digunakan pada mobile.

2. Menentukan prioritas elemen
a. Langkah pertama dalam menentukan prioritas elemen adalah membuat perbandingan pasangan, yaitu membandingkan elemen secara berpasangan sesuai kriteria yang diberikan.
b. Matriks perbandingan berpasangan diisi menggunakan bilangan untuk merepresentasikan kepentingan relatif dari suatu elemen terhadap elemen yang lainnya.

3. Sintesis

Pertimbangan-pertimbangan terhadap perbandingan berpasangan disintesis untuk memperoleh keseluruhan prioritas. Hal-hal yang dilakukan dalam langkah ini adalah:

a. Menjumlahkan nilai-nilai dari setiap kolom pada matriks.

b. Membagi setiap nilai dari kolom dengan total kolom yang bersangkutan untuk memperoleh normalisasi matriks.

c. Menjumlahkan nilai-nilai dari setiap baris dan membaginya dengan jumlah elemen untuk mendapat nilai rata-rata.

4. Mengukur konsistensi

Dalam pembuatan keputusan, penting untuk mengetahui seberapa baik konsistensi yang ada karena kita tidak menginginkan keputusan berdasarkan pertimbangan dengan konsistensi yang rendah. Hal-hal yang dilakukan dalam langkah ini adalah:

a. Kalikan setiap nilai pada kolom pertama dengan prioritas relatif elemen pertama, nilai pada kolom kedua dengan prioritas relatif elemen kedua, dan seterusnya.

b. Jumlahkan setiap baris.

c. Hasil dari penjumlahan baris dibagi dengan banyaknya elemen yang ada, hasilnya disebut $\lambda$ maks.

5. Hitung Consistency Index (CI) dengan rumus:

$$
\mathrm{CI}=\frac{(\lambda m a k s-n)}{n}
$$

Dimana: $\mathrm{n}=$ banyaknya elemen

6. Hitung Rasio Konsistensi/Consistency Ratio (CR) dengan rumus:

$$
\begin{aligned}
& \mathrm{CR}=\frac{C I}{R C} \\
& \text { Dimana: } \\
& \mathrm{CR}=\text { Consistency Ratio } \\
& \mathrm{CI}=\text { Consistency Index } \\
& \mathrm{IR}=\text { Indeks Random Consistency }
\end{aligned}
$$

7. Memeriksa konsistensi hierarki. Jika nilainya lebih dari $10 \%$, maka penilaian data judgement harus diperbaiki. Namun jika rasio konsistensi (CI/CR) kurang atau sama dengan 0,1, maka hasil perhitungan bisa dinyatakan benar.

Daftar indeks Random Konsistensi (IR) yaitu:

Tabel 1.

Daftar Indeks Random Konsistensi

\begin{tabular}{|c|c|c|c|c|c|c|c|c|c|c|}
\hline Crdo & 1 & 2 & 3 & 4 & 5 & 6 & 7 & 8 & 9 & 10 \\
\hline Rा & 0 & 0 & 0,58 & 0,90 & 1,12 & 1,24 & 1,32 & 1,41 & 1,45 & 1,49 \\
\hline
\end{tabular}

Sumber : (Haramaini, Nasution, \& Sulaiman, 2018)

\section{HASIL DAN PEMBAHASAN}

Analisis Data

Data yang digunakan pada penelitian ini berasal dari kuesioner yang telah diisi oleh responden. Data diambil dengan membuat kriteria

\begin{tabular}{|c|c|}
\hline Kriteria & Alternatif \\
\hline Konsumsi RAM & \multirow{5}{*}{$\begin{array}{l}\text { 1. Opera Mini } \\
\text { 2. UC Browser } \\
\text { 3. Chrome }\end{array}$} \\
\hline Kecepatan & \\
\hline Fitur & \\
\hline Keamanan & \\
\hline Hemat Kuota & \\
\hline
\end{tabular}
dan alternatif pilihan, dalam memiilih web browser pada mobile. Berikut kriteria dan alternatif yang digunakan:

Tabel 2.

Kriteria dan Alternatif

Sumber: Hasil Penelitian (2020)

\section{Struktur Hirarki}

Berdasarkan kriteria dan alternatif yang telah diambil, maka disusunlah dalam sebuah hirarki agar lebih mempermudah dalam pengolahan data. 
Penyusunan hirarki dibuat untuk menggambarkan tujuan yang ingin dicapai dalam penelitian. Adapun hirarki yang dibuat berdasarkan kriteria dan alternatif adalah sebagai berikut:

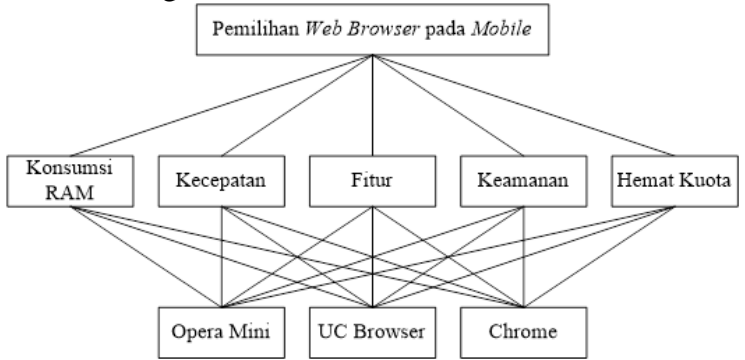

Sumber: Hasil Penelitian (2020)

Gambar 1. Hirarki Pemilihan Web Browser pada Mobile

\section{Pengolahan Data}

Dari hasil pengisian kuesioner yang telah disebarkan kepada responden, pertama data dibuat dalam bentuk matriks perbandingan berpasangan, untuk mendapatkan bobot dari kriteria masing-masing

\section{Kriteria Utama}

Matriks berpasangan untuk kriteria utama dari data kuesioner yang diolah menghasilkan tabel sebagai berikut:

Tabel 3.

Matriks Kriteria Utama

\begin{tabular}{|l|c|c|c|c|c|}
\hline \multicolumn{1}{|c|}{ Kriteria } & $\begin{array}{c}\text { Konsumsi } \\
\text { RAM }\end{array}$ & Kecepatan & Fitur & Keamanan & $\begin{array}{c}\text { Hemat } \\
\text { Kuota }\end{array}$ \\
\hline Konsumsi RA & 1,00 & 0,93 & 2,46 & 0,81 & 0,52 \\
\hline Kecepatan & 1,08 & 1,00 & 4,66 & 0,80 & 1,41 \\
\hline Fitur & 0,41 & 0,21 & 1,00 & 0,35 & 0,42 \\
\hline Keamanan & 1,23 & 1,25 & 2,89 & 1,00 & 1,33 \\
\hline $\begin{array}{l}\text { Hemat } \\
\text { Kuota }\end{array}$ & 1,92 & 0,71 & 2,35 & 0,75 & 1,00 \\
\hline \hline \multicolumn{1}{|c|}{ TOTAL } & 5,64 & 4,10 & 13,37 & 3,71 & 4,69 \\
\hline
\end{tabular}

Sumber: Hasil Penelitian (2020)

Selanjutnya menghitung nilai eigen vector yang dihasilkan dari rata-rata bobot relatif untuk setiap baris. Hasilnya dapat diperoleh pada tabel berikut:

Tabel 4.

Normalisasi Matriks Kriteria Utama

\begin{tabular}{|l|c|c|c|c|c||c|}
\hline Kriteria & $\begin{array}{c}\text { Konsumsi } \\
\text { RAM }\end{array}$ & Kecepatan & Fitur & Keamanan & $\begin{array}{c}\text { Hemat } \\
\text { Kuota }\end{array}$ & $\begin{array}{c}\text { Rata } \\
\text { rata }\end{array}$ \\
\hline $\begin{array}{l}\text { Konsums } \\
\text { RAM }\end{array}$ & 0,18 & 0,23 & 0,18 & 0,22 & 0,11 & 0,18 \\
\hline Kecepatan & 0,19 & 0,24 & 0,35 & 0,22 & 0,30 & 0,26 \\
\hline Fitur & 0,07 & 0,05 & 0,07 & 0,09 & 0,09 & 0,08 \\
\hline Keamanan & 0,22 & 0,30 & 0,22 & 0,27 & 0,28 & 0,26 \\
\hline $\begin{array}{l}\text { Hemat } \\
\text { Kuota }\end{array}$ & 0,34 & 0,17 & 0,18 & 0,20 & 0,21 & 0,22 \\
\hline \hline
\end{tabular}

Sumber: Hasil Penelitian (2020)

Selanjutnya nilai eigen vector dikalikan dengan matriks awal, menghasilkan nilai untuk tiap baris, yang selanjutnya setiap nilai dibagi kembali dengan nilai vector yang bersangkutan. Nilai ratarata dari hasil pembagian ini merupakan principal eigen value maksimum ( $\lambda$ Maks).
Perhitungan:

$\left[\begin{array}{ccccc}1,00 & 0,93 & 2,46 & 0,81 & 0,52 \\ 1,08 & 1,00 & 4,66 & 0,80 & 1,41 \\ 0,41 & 0,21 & 1,00 & 0,35 & 0,42 \\ 1,23 & 1,25 & 2,89 & 1,00 & 1,33 \\ 1,92 & 0,71 & 2,35 & 0,75 & 1,00\end{array}\right] \times\left[\begin{array}{l}0,18 \\ 0,26 \\ 0,08 \\ 0,26 \\ 0,22\end{array}\right]$
$=\left[\begin{array}{l}0,94 \\ 1,33 \\ 0,39 \\ 1,32 \\ 1,13\end{array}\right]$

Consistency Vector

$\left[\begin{array}{l}0,94 \\ 1,33 \\ 0,39 \\ 1,32 \\ 1,13\end{array}\right]: \quad\left[\begin{array}{l}0,18 \\ 0,26 \\ 0,08 \\ 0,26 \\ 1,13\end{array}\right]=\left[\begin{array}{l}5,11 \\ 5,13 \\ 5,10 \\ 5,13 \\ 5,12\end{array}\right]$

$\lambda$ Maks $=\frac{5,11+5,13+5,10+5,13+5,12}{5}=5,12$

Selanjutnya adalah mencari nilai consistency index. Dengan $\mathrm{n}=5$.

$\mathrm{CI}=\frac{(\lambda \text { maks }-\mathrm{n})}{(\mathrm{n}-1)}=\frac{(5,12-5)}{(5-1)}=0,03$

Karena matriks berordo 5 (yakni terdiri dari 5 kriteria), maka random index (RI) adalah 1,12.

$\mathrm{CR}=\frac{\mathrm{CI}}{\mathrm{RI}}=\frac{0,03}{1,12}=0,03$

Dengan hasil $\mathrm{CR}<0,1$ maka preferensi responden konsisten.

Dari hasil perhitungan pada tabel kriteria utama diatas menunjukkan bahwa kecepatan dan keamanan merupakan kriteria yang paling penting dalam pemilihan web browser pada mobile dengan nilai bobot masing-masing sebesar 0,26 atau 26\%, kedua adalah hemat kuota dengan nilai bobot sebesar 0,22 atau $22 \%$, selanjutnya adalah konsumsi RAM dengan nilai bobot sebesar 0,18 atau $18 \%$, terakhir adalah fitur dengan nilai bobot sebesar 0,08 atau $8 \%$.

2. Kriteria Konsumsi RAM

Matriks berpasangan untuk kriteria konsumsi RAM dari data kuesioner yang diolah menghasilkan tabel sebagai berikut:

Tabel 5.

Matriks Konsumsi RAM

\begin{tabular}{|c|c|c|c|}
\hline \multicolumn{1}{|c|}{ Kriteria } & Opera Mini & UC Browser & Chrome \\
\hline Opera Mini & 1,00 & 0,56 & 1,02 \\
\hline UC Browser & 1,79 & 1,00 & 1,93 \\
\hline Chrome & 0,98 & 0,52 & 1,00 \\
\hline TOTAL & 3,77 & 2,08 & 3,95 \\
\hline
\end{tabular}

Sumber: Hasil Penelitian (2020) 
Setelah didapat total dari tiap unsur, selanjutnya hitung bobot relatif yang dinormalkan dengan cara unsur-unsur tiap kolom di bagi dengan jumlah kolom yang bersangkutan. Selanjutnya menghitung nilai eigen vector yang dihasilkan dari rata-rata bobot relatif untuk setiap baris. Hasilnya dapat diperoleh pada tabel berikut:

Tabel 6.

Normalisasi Matriks Konsumsi RAM

\begin{tabular}{|l|c|c|c||c|}
\hline \multicolumn{1}{|c|}{ Kriteria } & $\begin{array}{c}\text { Opera } \\
\text { Mini }\end{array}$ & C Brows & Chrome & Rata-rata \\
\hline Opera Mini & 0,27 & 0,27 & 0,26 & 0,27 \\
\hline UC Browser & 0,47 & 0,48 & 0,49 & 0,48 \\
\hline Chrome & 0,26 & 0,25 & 0,25 & 025 \\
\hline \hline \multicolumn{4}{|c||}{ Eigen Vector } & 1,00 \\
\hline
\end{tabular}

Sumber: Hasil Penelitian (2020)

Selanjutnya nilai eigen vector dikalikan dengan matriks awal, menghasilkan nilai untuk tiap baris, yang selanjutnya setiap nilai dibagi kembali dengan nilai vector yang bersangkutan. Nilai ratarata dari hasil pembagian ini merupakan principal eigen value maksimum ( $\lambda$ Maks).

Perhitungan:

$\left[\begin{array}{lll}1,00 & 0,56 & 1,02 \\ 1,79 & 1,00 & 1,93 \\ 0,98 & 0,52 & 1,00\end{array}\right] \times \quad\left[\begin{array}{l}0,27 \\ 0,48 \\ 0,25\end{array}\right]=\left[\begin{array}{l}0,79 \\ 1,44 \\ 0,76\end{array}\right]$

Consistency Vector

$\left[\begin{array}{l}0,79 \\ 1,44 \\ 0,76\end{array}\right] \quad: \quad\left[\begin{array}{l}0,27 \\ 0,48 \\ 0,25\end{array}\right]=\left[\begin{array}{l}3,00 \\ 3,00 \\ 3,00\end{array}\right]$

$\lambda$ Maks $=\frac{3,00+3,00+3,00}{3}=3,00$

Selanjutnya adalah mencari nilai consistency index. Dengan $\mathrm{n}=3$.

$\mathrm{CI}=\frac{(\lambda \text { maks }-\mathrm{n})}{(\mathrm{n}-1)}=\frac{(3,00-3)}{(3-1)}=0,00$

Karena matriks berordo 3 (yakni terdiri dari 3 alternatif), maka random index (RI) adalah 0,58.

$\mathrm{CR}=\frac{\mathrm{CI}}{\mathrm{RI}}=\frac{0,00}{0,58}=0,00$

Dengan hasil $\mathrm{CR}<0,1$ maka preferensi responden konsisten.

Dari hasil perhitungan pada tabel kriteria konsumsi RAM diatas menunjukkan bahwa $U C$ Browser merupakan alternatif yang paling penting dalam pemilihan web browser pada mobile dengan nilai bobot sebesar 0,48 atau $48 \%$, selanjutnya adalah Opera Mini dengan nilai bobot sebesar 0,27 atau $27 \%$, dan terakhir adalah Chrome dengan nilai bobot sebesar 0,25 atau $25 \%$

\section{Kriteria Kecepatan}

Matriks berpasangan untuk kriteria kecepatan dari data kuesioner yang diolah menghasilkan tabel sebagai berikut:
Tabel 7.

Matriks Kecepatan

\begin{tabular}{|l|c|c|c|}
\hline \multicolumn{1}{|c|}{ Kriteria } & Opera Mini & UC Browser & Chrome \\
\hline Opera Mini & 1,00 & 0,44 & 0,49 \\
\hline UC Browser & 2,30 & 1,00 & 1,37 \\
\hline Chrome & 2,03 & 0,73 & 1,00 \\
\hline \hline TOTAL & 5,33 & 2,17 & 2,86 \\
\hline
\end{tabular}

Sumber: Hasil Penelitian (2020)

Setelah didapat total dari tiap unsur, selanjutnya hitung bobot relatif yang dinormalkan dengan cara unsur-unsur tiap kolom di bagi dengan jumlah kolom yang bersangkutan. Selanjutnya menghitung nilai eigen vector yang dihasilkan dari rata-rata bobot relatif untuk setiap baris. Hasilnya dapat diperoleh pada tabel berikut:

Tabel 8.

Normalisasi Matriks Kecepatan

\begin{tabular}{|c|c|c|c||c|}
\hline Kriteria & Opera Mini & UC Browser & Chrome & Rata - rata \\
\hline Opera Mini & 0,19 & 0,20 & 0,17 & 0,19 \\
\hline UC Browse & 0,43 & 0,46 & 0,48 & 0,46 \\
\hline Chrome & 0,38 & 0,34 & 0,35 & 0,35 \\
\hline \hline \multicolumn{4}{|r|}{ Eigen Vector } & 1,00 \\
\hline
\end{tabular}

Sumber: Hasil Penelitian (2020)

Selanjutnya nilai eigen vector dikalikan dengan matriks awal, menghasilkan nilai untuk tiap baris, yang selanjutnya setiap nilai dibagi kembali dengan nilai vector yang bersangkutan. Nilai ratarata dari hasil pembagian ini merupakan principal eigen value maksimum ( $\lambda$ Maks).

Perhitungan:

$\left[\begin{array}{lll}1,00 & 0,44 & 0,49 \\ 2,30 & 1,00 & 1,37 \\ 2,03 & 0,73 & 1,00\end{array}\right] \times\left[\begin{array}{l}0,19 \\ 0,46 \\ 0,35\end{array}\right]=\left[\begin{array}{l}0,56 \\ 1,37 \\ 1,07\end{array}\right]$

Consistency Vector

$\left[\begin{array}{l}0,56 \\ 1,37 \\ 1,07\end{array}\right] \quad: \quad\left[\begin{array}{l}0,19 \\ 0,46 \\ 0,35\end{array}\right]=\left[\begin{array}{l}3,00 \\ 3,00 \\ 3,00\end{array}\right]$

$\lambda$ Maks $=\frac{3,00+3,01+3,00}{3}=3,00$

Selanjutnya adalah mencari nilai consistency index. Dengan $\mathrm{n}=3$.

$\mathrm{CI}=\frac{(\lambda \text { maks }-\mathrm{n})}{(\mathrm{n}-1)}=\frac{(3,00-3)}{(3-1)}=0,00$

Karena matriks berordo 3 (yakni terdiri dari 3 alternatif), maka random index (RI) adalah 0,58.

$\mathrm{CR}=\frac{\mathrm{CI}}{\mathrm{RI}}=\frac{0,00}{0,58}=0,00$

Dengan hasil $\mathrm{CR}<0,1$ maka preferensi responden konsisten.

Dari hasil perhitungan pada tabel kriteria kecepatan diatas menunjukkan bahwa UC Browser merupakan alternatif yang paling penting dalam pemilihan web browser pada mobile dengan nilai bobot sebesar 0,46 atau 46\%, selanjutnya adalah Chrome dengan nilai bobot sebesar 0,35 atau 35\%, 
dan terakhir adalah Opera Mini dengan nilai bobot sebesar 0,19 atau $19 \%$.

\section{Kriteria Fitur}

Matriks berpasangan untuk kriteria fitur dari data kuesioner yang diolah menghasilkan tabel sebagai berikut:

Tabel 9. Matriks Fitur

\begin{tabular}{|l|c|c|c|}
\hline \multicolumn{1}{|c|}{ Kriteria } & Opera Mini & UC Browser & Chrome \\
\hline Opera Mini & 1,00 & 0,45 & 0,79 \\
\hline UC Browser & 2,21 & 1,00 & 2,00 \\
\hline Chrome & 1,27 & 0,50 & 1,00 \\
\hline \hline TOTAL & 4,48 & 1,95 & 3,79 \\
\hline
\end{tabular}

Sumber: Hasil Penelitian (2020)

Setelah didapat total dari tiap unsur, selanjutnya hitung bobot relatif yang dinormalkan dengan cara unsur-unsur tiap kolom di bagi dengan jumlah kolom yang bersangkutan. Selanjutnya menghitung nilai eigen vector yang dihasilkan dari rata-rata bobot relatif untuk setiap baris. Hasilnya dapat diperoleh pada tabel berikut:

Tabel 10.

Normalisasi Matriks Fitur

\begin{tabular}{|l|c|c|c||c|}
\hline \multicolumn{1}{|c|}{ Kriteria } & Opera Mini & IC Browse & Chrome & Rata - rata \\
\hline Opera Mini & 0,22 & 0,23 & 0,21 & 0,22 \\
\hline UC Browser & 0,49 & 0,51 & 0,53 & 0,51 \\
\hline Chrome & 0,28 & 0,26 & 0,36 & 0,27 \\
\hline \hline \multicolumn{4}{|c|}{ Eigen Vector } & 1,00 \\
\hline
\end{tabular}

Sumber: Hasil Penelitian (2020)

Selanjutnya nilai eigen vector dikalikan dengan matriks awal, menghasilkan nilai untuk tiap baris, yang selanjutnya setiap nilai dibagi kembali dengan nilai vector yang bersangkutan. Nilai ratarata dari hasil pembagian ini merupakan principal eigen value maksimum ( $\lambda$ Maks).

Perhitungan:

$\left[\begin{array}{lll}1,00 & 0,45 & 0,79 \\ 2,21 & 1,00 & 2,00 \\ 1,27 & 0,50 & 1,00\end{array}\right] \times \quad\left[\begin{array}{l}0,22 \\ 0,51 \\ 0,27\end{array}\right]=\left[\begin{array}{l}0,66 \\ 1,53 \\ 0,80\end{array}\right]$

Consistency Vector

$\left[\begin{array}{l}0,66 \\ 1,53 \\ 0,80\end{array}\right]: \quad\left[\begin{array}{l}0,22 \\ 0,51 \\ 0,27\end{array}\right]=\left[\begin{array}{l}3,00 \\ 3,00 \\ 3,00\end{array}\right]$
$\lambda$ Maks $=\frac{3,00+3,00+3,00}{3}=3,00$

Selanjutnya adalah mencari nilai consistency index. Dengan $\mathrm{n}=3$.

$\mathrm{CI}=\frac{(\lambda \text { maks }-\mathrm{n})}{(\mathrm{n}-1)}=\frac{(3,00-3)}{(3-1)}=0,00$

Karena matriks berordo 3 (yakni terdiri dari 3 alternatif), maka random index (RI) adalah 0,58.

$\mathrm{CR}=\frac{\mathrm{CI}}{\mathrm{RI}}=\frac{0,00}{0,58}=0,00$

Dengan hasil $\mathrm{CR}<0,1$ maka preferensi responden konsisten.
Dari hasil perhitungan pada tabel kriteria fitur diatas menunjukkan bahwa UC Browser merupakan alternatif yang paling penting dalam pemilihan web browser pada mobile dengan nilai bobot sebesar 0,51 atau $51 \%$, selanjutnya adalah Chrome dengan nilai bobot sebesar 0,27 atau $27 \%$, dan terakhir adalah Opera Mini dengan nilai bobot sebesar 0,22 atau $22 \%$.

\section{Kriteria Keamanan}

Matriks berpasangan untuk kriteria keamanan dari data kuesioner yang diolah menghasilkan tabel sebagai berikut:

Tabel 11.

Matriks Keamanan

\begin{tabular}{|l|c|c|c|}
\hline \multicolumn{1}{|c|}{ Kriteria } & Opera Mini & UC Browser & Chrome \\
\hline Opera Mini & 1,00 & 0,52 & 0,41 \\
\hline UC Browser & 1,91 & 1,00 & 0,83 \\
\hline Chrome & 2,44 & 1,20 & 1,00 \\
\hline \hline TOTAL & 5,35 & 2,73 & 2,24 \\
\hline
\end{tabular}

Sumber: Hasil Penelitian (2020)

Setelah didapat total dari tiap unsur, selanjutnya hitung bobot relatif yang dinormalkan dengan cara unsur-unsur tiap kolom di bagi dengan jumlah kolom yang bersangkutan. Selanjutnya menghitung nilai eigen vector yang dihasilkan dari rata-rata bobot relatif untuk setiap baris. Hasilnya dapat diperoleh pada tabel berikut:

Tabel 12.

Normalisasi Matriks Keamanan

\begin{tabular}{|l|c|c|c||c|}
\hline \multicolumn{1}{|c|}{ Kriteria } & $\begin{array}{c}\text { Opera } \\
\text { Mini }\end{array}$ & UC Browser & Chrome & Rata - rata \\
\hline Opera Mini & 0,19 & 0,19 & 0,18 & 0,19 \\
\hline UC Browser & 0,36 & 0,37 & 0,37 & 0,36 \\
\hline Chrome & 0,46 & 0,44 & 0,45 & 0,45 \\
\hline \hline \multicolumn{4}{|c|}{ Eigen Vector } & 1,00 \\
\hline
\end{tabular}

Sumber: Hasil Penelitian (2020)

Selanjutnya nilai eigen vector dikalikan dengan matriks awal, menghasilkan nilai untuk tiap baris, yang selanjutnya setiap nilai dibagi kembali dengan nilai vector yang bersangkutan. Nilai ratarata dari hasil pembagian ini merupakan principal eigen value maksimum ( $\lambda$ Maks).

Perhitungan:

$\left[\begin{array}{lll}1,00 & 0,52 & 0,41 \\ 1,01 & 1,00 & 0,83 \\ 2,44 & 1,20 & 1,00\end{array}\right] \times\left[\begin{array}{l}0,19 \\ 0,36 \\ 0,45\end{array}\right]=\left[\begin{array}{l}0,56 \\ 1,09 \\ 1,34\end{array}\right]$

\section{Consistency Vector}

$\left[\begin{array}{l}0,56 \\ 1,09 \\ 1,34\end{array}\right] \quad: \quad\left[\begin{array}{l}0,19 \\ 0,36 \\ 0,45\end{array}\right]=\left[\begin{array}{l}3,00 \\ 3,00 \\ 3,00\end{array}\right]$

$\lambda$ Maks $=\frac{3,00+3,00+3,00}{3}=3,00$

Selanjutnya adalah mencari nilai consistency index. Dengan $\mathrm{n}=3$.

$\mathrm{CI}=\frac{(\lambda \text { maks }-\mathrm{n})}{(\mathrm{n}-1)}=\frac{(3,00-3)}{(3-1)}=0,00$ 
Karena matriks berordo 3 (yakni terdiri dari 3 alternatif), maka random index (RI) adalah 0,58.

$\mathrm{CR}=\frac{\mathrm{CI}}{\mathrm{RI}}=\frac{0,00}{0,58}=0,00$

Dengan hasil $\mathrm{CR}<0,1$ maka preferensi responden konsisten.

Dari hasil perhitungan pada tabel kriteria keamanan diatas menunjukkan bahwa Chrome merupakan alternatif yang paling penting dalam pemilihan web browser pada mobile dengan nilai bobot sebesar 0,45 atau $45 \%$, selanjutnya adalah $U C$ Browser dengan nilai bobot sebesar 0,36 atau 36\%, dan terakhir adalah Opera Mini dengan nilai bobot sebesar 0,19 atau $19 \%$.

\section{Kriteria Hemat Kuota}

Matriks berpasangan untuk kriteria hemat kuota dari data kuesioner yang diolah menghasilkan tabel sebagai berikut:

Tabel 13.

Kriteria Hemat Kuota

\begin{tabular}{|l|c|c|c|}
\hline \multicolumn{1}{|c|}{ Kriteria } & Opera Mini & C Brows & Chrome \\
\hline Opera Mini & 1,00 & 0,99 & 1,50 \\
\hline UC Browser & 1,01 & 1,00 & 1,44 \\
\hline Chrome & 0,67 & 0,69 & 1,00 \\
\hline \hline TOTAL & 2,68 & 2,68 & 3,94 \\
\hline
\end{tabular}

Sumber: Hasil Penelitian (2020)

Setelah didapat total dari tiap unsur, selanjutnya hitung bobot relatif yang dinormalkan dengan cara unsur-unsur tiap kolom di bagi dengan jumlah kolom yang bersangkutan. Selanjutnya menghitung nilai eigen vector yang dihasilkan dari rata-rata bobot relatif untuk setiap baris. Hasilnya dapat diperoleh pada tabel berikut:

Tabel 14.

Normalisasi Matriks Hemat Kuota

\begin{tabular}{|c|c|c|c||c|}
\hline Kriteria & Opera Mini & C Brows & Chrome & Rata - rata \\
\hline Opera Mini & 0,37 & 0,37 & 0,38 & 0,37 \\
\hline UC Browse & 0,38 & 0,37 & 0,37 & 0,37 \\
\hline Chrome & 0,25 & 0,26 & 0,25 & 0,25 \\
\hline \hline \multicolumn{4}{r||}{ Eigen Vector } & 1,00 \\
\hline
\end{tabular}

Sumber: Hasil Penelitian (2020)

Selanjutnya nilai eigen vector dikalikan dengan matriks awal, menghasilkan nilai untuk tiap baris, yang selanjutnya setiap nilai dibagi kembali dengan nilai vector yang bersangkutan. Nilai ratarata dari hasil pembagian ini merupakan principal eigen value maksimum ( $\lambda$ Maks).

Perhitungan:

$\left[\begin{array}{lll}1,00 & 0,99 & 1,50 \\ 1,01 & 1,00 & 1,44 \\ 0,67 & 0,69 & 1,00\end{array}\right] \times\left[\begin{array}{l}0,37 \\ 0,37 \\ 0,25\end{array}\right]=\left[\begin{array}{l}1,12 \\ 1,12 \\ 0,76\end{array}\right]$

\section{Consistency Vector}

$\left[\begin{array}{l}1,12 \\ 1,12 \\ 0,76\end{array}\right]: \quad\left[\begin{array}{l}0,37 \\ 0,37 \\ 0,25\end{array}\right]=\left[\begin{array}{l}3,00 \\ 3,00 \\ 3,00\end{array}\right]$
$\lambda$ Maks $=\frac{3,00+3,00+3,00}{3}=3,00$

Selanjutnya adalah mencari nilai consistency index. Dengan $\mathrm{n}=3$.

$\mathrm{CI}=\frac{(\lambda \text { maks }-\mathrm{n})}{(\mathrm{n}-1)}=\frac{(3,00-3)}{(3-1)}=0,00$

Karena matriks berordo 3 (yakni terdiri dari 3 alternatif), maka random index (RI) adalah 0,58.

$\mathrm{CR}=\frac{\mathrm{CI}}{\mathrm{RI}}=\frac{0,00}{0,58}=0,00$

Dengan hasil $\mathrm{CR}<0,1$ maka preferensi responden konsisten.

Dari hasil perhitungan pada tabel kriteria hemat kuota diatas menunjukkan bahwa Opera Mini dan UC Browser merupakan alternatif yang paling penting dalam pemilihan web browser pada mobile dengan nilai bobot masing-masing sebesar 0,37 atau $37 \%$, dan terakhir adalah Chrome dengan nilai bobot sebesar 0,25 atau $25 \%$.

\section{Hasil Akhir Pengolahan Data Manual}

Setelah melakukan perhitungan data dari hasil pengisian kuesioner, keseluruhan perhitungan memperoleh hasil sebagai berikut:

$\left[\begin{array}{lllll}0,26 & 0,19 & 0,22 & 0,19 & 0,37 \\ 0,48 & 0,46 & 0,51 & 0,36 & 0,37 \\ 0,25 & 0,36 & 0,27 & 0,45 & 0,25\end{array}\right] \times\left[\begin{array}{l}0,18 \\ 0,26 \\ 0,08 \\ 0,26 \\ 0,22\end{array}\right]=$

$\left[\begin{array}{l}0,2552 \\ 0,4231\end{array}\right.$

[0,3318

Tabel 15

Hasil Perhitungan Akhir

\begin{tabular}{|c|c|}
\hline Opera Mini & 0,2552 \\
\hline UC Browser & 0,4231 \\
\hline Chrome & 0,3318 \\
\hline
\end{tabular}

\section{KESIMPULAN}

Dari hasil penelitian dan penggolahan data pada penelitian ini, didapatkan kesimpulan sebagai berikut:

1. Kecepatan ialah faktor prioritas dalam pemilihan web browser pada mobile.

2. UC Browser dinilai sebagai aplikasi mobile web browser yang terbaik.

3. Dari setiap kriteria memiliki aplikasi web browser terbaik, yaitu:
a. Kriteria konsumsi RAM unggul UC Browser.
b. Kriteria kecepatan unggul UC Browser.
c. Kriteria fitur unggul UC Browser. 
d. Kriteria keamanan unggul Chrome.

e. Kriteria hemat kuota unggul Opera Mini dan UC Browser.

4. Dari hasil perhitungan manual dan menggunakan sofware expert choice berikut grafik yang dihasilkan:

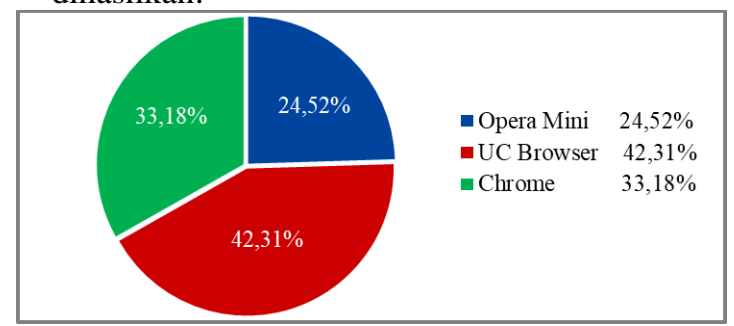

Sumber : Hasil Penelitian (2020)

Gambar 2. Grafik Hasil Akhir Perhitungan Manual

\section{REFERENSI}

Andiarna, F., Widayanti, L. P., Hidayati, I., Agustina, E., \& Kunci, K. (2020). Analisis Penggunaan Media Sosial Terhadap Kejadian Insomnia Pada Mahasiswa Analysis Of Social Media Usage With Insomnia Incidence Among Students. PROFESI (Profesional Islam): Media Publikasi Penelitian (Vol. 17). Retrieved from https://journals.itspku.ac.id/index.php/profesi/ article/view/26

Andri Sulistyo, 5302411195. (2016). MODEL SISTEM ELECTRONIC VOTING (EVOTING) BERBASIS WEB DENGAN MENERAPKAN QUICK RESPONSE CODE (QR-CODE) SEBAGAI SISTEM KEAMANAN DALAM PEMILIHAN LEGISLATIF.

Fadli, S., Taufan, M., \& Zaen, A. (2018). JISA (Jurnal Informatika dan Sains) Penggunaan Metode Techique for Order Preference by Similarity to Ideal Solution (TOPSIS) untuk Evaluasi Kinerja Dosen oleh Mahasiswa (Studi Kasus: STMIK Lombok). JISA (Jurnal Informatika Dan Sains), 01(01). Retrieved from

http://www.universitastrilogi.ac.id/journal/ks/i ndex.php/JISA/article/view/295

Fridayanthie, E. W., Mahdiati, T., Studi, P., Informatika, M., Bsi, A., Bumi, T., ... Tangerang, S. (2016). RANCANG BANGUN SISTEM INFORMASI PERMINTAAN ATK BERBASIS INTRANET (STUDI KASUS: KEJAKSAAN NEGERI RANGKASBITUNG). Jurnal Khatulistiwa Informatika (Vol. IV). https://doi.org/10.31294/JKI.V4I2.1264

Gandys Marisha Utami, 14423085. (2018).
PENGARUH MEREK DAN FITUR TERHADAP KEPUTUSAN KONSUMEN DALAM MEMILIH SMARTPHONE DI YOGYAKARTA DENGAN RASIONALITAS EKONOMI ISLAM SEBAGAI MODERATING The Influence of Brand Image and features on Consumer Decisions in Choosing a Smartphone in Yogyakarta with the Islamic Economics Rationality as a moderating. Universitas Islam Indonesia. Retrieved from https://dspace.uii.ac.id/handle/123456789/990 6

Haramaini, T., Nasution, K., \& Sulaiman, O. K. (2018). PENERAPAN METODE ANALYTICAL HIERARCHY PROCESS (AHP) DALAM MENENTUKAN TINGKAT KEMACETAN LALULINTAS DI KECAMATAN MEDAN KOTA. MULTITEK INDONESIA, $12(1), \quad 8$. https://doi.org/10.24269/mtkind.v12i1.711

Minge, M., Thüring, M., Wagner, I., \& Kuhr, C. V. (2017). The meCUE questionnaire: A modular tool for measuring user experience. In Advances in Intelligent Systems and Computing (Vol. 486, pp. 115-128). Springer Verlag. https://doi.org/10.1007/978-3-31941685-4_11

Mujiastuti, R., Meilina, P., \& Afridhon Iwan Pramudiaji, dan. (2017). PENGGUNAAN METODE AHP DALAM MENENTUKAN INDIVIDUAL DEVELOPMENT PLAN UNTUK MENGUKUR KOMPETENSI TEKNIS PEKERJA. Popy Meilina Jurnal Sistem Informasi, 7(2), 1-10. Retrieved from https://jurnal.umj.ac.id/index.php/justit/article/view/1069

Prasetiadi, A. E. (2011). WEB 3.0: TEKNOLOGI WEB MASA DEPAN. Jurnal Industri Elektro dan Penerbangan (Vol. 1). Retrieved from http://jurnal.unnur.ac.id/index.php/indept/articl e/view/78

Rahmadoni, J. (2018). Perancangan Simulasi Pembelajaran Kriptografi Klasik Menggunakan Metode Web Based Learning. INTECOMS: Journal of Information Technology and Computer Science, 1(1), 3443. https://doi.org/10.31539/intecoms.v1i1.160

Yosua, Y., Agus, F., \& Astuti, I. F. (2017). SISTEM PENDUKUNG KEPUTUSAN PEMILIHAN PAKET KARTU HALO MENGGUNAKAN METODE AHP BERBASIS WEB. Prosiding Seminar Nasional Ilmu Komputer Dan Teknologi Informasi, 2(2). 